\title{
Interactive comment on "The PMIP4-CMIP6 Last Glacial Maximum experiments: preliminary results and comparison with the PMIP3-CMIP5 simulations" by Masa Kageyama et al.
}

Masa Kageyama et al.

masa.kageyama@Isce.jpsl.fr

Received and published: 29 October 2020

Our reply is provided in the attached document.

Please also note the supplement to this comment:

https://cp.copernicus.org/preprints/cp-2019-169/cp-2019-169-AC1-supplement.pdf

Interactive comment on Clim. Past Discuss., https://doi.org/10.5194/cp-2019-169, 2020. 